\title{
Stability of Bulk Heterojunction Organic Solar Cells with Different Blend Ratios of P3HT:PCBM
}

\author{
Moo Hyun Kwon ${ }^{+}$ \\ Department of Applied Chemistry, Woosuk University, Wanju 565-701, Korea
}

Received December 23, 2011; Revised February 13, 2012; Accepted February 20, 2012

I studied the stability of organic photovoltaic cells in terms of P3HT:PCBM-71 blend ratio as a function of storage time. I obtained the best cell performance by optimizing the blend ratio of electron donor and electron acceptor within the active layer. In this study, I found that the more the P3HT:PCBM ratio increases within the active layer, the more the cell efficiency decreases as the storage time increases. As a result, the best optimized blend ratio was the 1:0.6 ratio of P3HT:PCBM-71, and cell efficiency of the device with the 1:0.6 blend ratio was 4.49\%. The device with the best cell efficiency showed good stability.

Keywords: Stability, Photovoltaic device, Bulk heterojunction, Active layer, Blend ratio

\section{INTRODUCTION}

Photovoltaic cells will hopefully lead to a clean and renewable energy source. Organic thin-film solar cells have potential advantages of low manufacturing cost, lightweight, and mechanical flexibility. In recent years, organic blend solar cells of conjugated polymer and fullerene derivative have shown improved efficiencies [1-8]. In particular, a poly(3-hexylthiophene) (P3HT) and [6,6]-phenyl-C71-butyric acid methyl ester (PCBM) blend system has attracted the most attention. Recently, P3HT:PCBM blend solar cells achieving a power conversion efficiency (PCE) approaching 5\% have been reported [9-11]. However, the major obstacles for the large-scale use of organic photovoltaics are their low efficiency and short lifetime. There have been some studies reporting the stability of devices under ambient conditions without encapsulation or with simple mechanical protection of the active layer with no barrier properties. All of these studies report a relatively short lifetime [12-20]. There are many applications where efficiencies of $1 \%$ or less are more than sufficient (e.g. small calculators, clocks, price tags, thermometers etc.). In this

${ }^{\dagger}$ Author to whom all correspondence should be addressed:

E-mail: k39@hanmail.net

Copyright $\odot 2012$ KIEEME. All rights reserved.

This is an open-access article distributed under the terms of the Creative Commons Attribution Non-Commercial
License (http://creativecommons.org/licenses/by-nc/3.0) which permits unrestricted noncommercial use, License (http://creativecommons.org/icenses/by-nc/3.0) which permits unrestricted
distribution, and reproduction in any medium, provided the original work is properly cited case, the only obstacle is the lifetime of the devices.

However, the degradation of organic solar cells has not yet been studied in any detail. It is clear that device efficiency depends critically on the spatial organization of the different materials into layers, with a precise thickness tailored for optimum photon harvesting and charge-carrier transport. In bulk heterojunction devices, a further requirement is the nanophase separation of the active layer into an interpenetrating network of donor and acceptor material.

The best methods to obtain this structure/morphology have been at the center of OPV research for a number of years. Small organic molecules like PCBM and even polymers like P3HT may still have some freedom to diffuse slowly or to recrystallize over time, especially at elevated temperatures. The best structure for device performance will in all probability not be the most thermodynamically stable. These gradual changes in the microstructure will lead to degradation of the performance of the OPVs [21].

Herein, I report the results on stability of the organic solar cells with different blend ratios of P3HT and PCBM. I have investigated the variation of organic photovoltaic performances as a function of storage time under AM 1.5 illumination (at 100 $\mathrm{mW} / \mathrm{cm}^{2}$ ). The best optimized blend ratio was the 1:0.6 ratio of P3HT:PCBM and cell efficiency of the device with the 1:0.6 blend ratio was $4.49 \%$. The device with the best cell efficiency indicated good stability. 

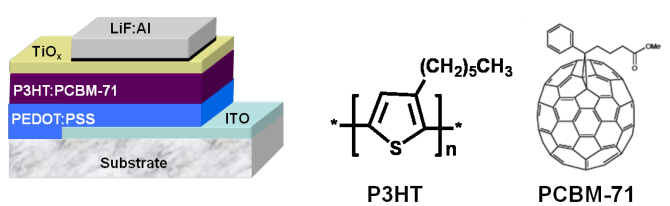

Fig. 1. Schematic (a) device structure of bulk heterojunction organic solar cell and (b) chemical structures used in this work.

\section{EXPERIMENTS}

Organic solar cell devices were fabricated by a spin-coating process. The device structure and chemical structures of the materials used in this study are shown in Figure 1. I used P3HT with high regioregularity as an electron donor (Aldrich) and PCBM-71 as an electron acceptor (ADS). These materials were used without further purification.

Polymer solar cells were prepared according to the following procedure. The patterned ITO glass substrate was first cleaned with acetone and IPA ultrasonically, and subsequently dried by $\mathrm{N}_{2}$ purging after being rinsed with DI water. Highly conducting polymer PEDOT:PSS (Heraeus, AI4083) was spin coated with a thickness of $\sim 50 \mathrm{~nm}$ from an aqueous solution. The substrate was cured for $20 \mathrm{~min}$ at $120^{\circ} \mathrm{C}$ on the hotplate in a glove box to remove the solvent. The dichlorobenzene solution composed of P3HT and PCBM-71 was then spin-cast with a thickness of $\sim 100$ $\mathrm{nm}$ at $700 \mathrm{rpm}$ on top of the PEDOT:PSS layer. Subsequently, the active layer was annealed for $30 \mathrm{~min}$ at $130^{\circ} \mathrm{C}$ on the hot plate, and then the $\mathrm{TiO}_{\mathrm{x}}$ solution prepared by sol-gel method was spincast on top of the active layer.

The $\mathrm{TiO}_{\mathrm{x}}$ precursor solution was prepared by sol-gel procedure [22]. Prior to usage, the 3-necked flask $(100 \mathrm{~mL})$ was heated at $120^{\circ} \mathrm{C}$ with flowing dry $\mathrm{N}_{2}$ to remove any moisture from inside the flask. The sol-gel procedure starts with the injection of the precursor, $5 \mathrm{~mL}$ titanium (IV) isopropoxide, followed by injection of $20 \mathrm{~mL} 2$-methoxyethanol and $2 \mathrm{~mL}$ ethanolamine into the 3-necked flask connected with a water condenser and $\mathrm{N}_{2}$ gas. Starting materials must be injected in this order. After one hour stirring at RT, the mixed solution was heated at $80^{\circ} \mathrm{C}$ for an hour, followed by heating to $120^{\circ} \mathrm{C}$ for one hour. During all procedures, the inside of the flask must be under dry $\mathrm{N}_{2}$ atmosphere and the mixed solution must be stirred continuously. After heating at $120^{\circ} \mathrm{C}$ for one hour, the solution transformed to a low-density gel of dark wine color.

After the obtained $\mathrm{TiO}_{x}$ solution spin-coats onto the active layer, during $1 \mathrm{~h}$ in air at room temperature, the precursor is converted to $\mathrm{TiO}_{\mathrm{x}}$ by hydrolysis. The cell was then heated at $150^{\circ} \mathrm{C}$ for $10 \mathrm{~min}$ inside a glove box filled with nitrogen. Then the device was thermally deposited under vacuum $\left(<10^{-7}\right.$ Torr $)$ on the top with a $\sim 0.5 \mathrm{~nm} \mathrm{LiF}$ and $\sim 100 \mathrm{~nm} \mathrm{Al}$. All the fabricated cells were encapsulated by using the UV curable resin in a $\mathrm{N}_{2}$ filled glove box. The active area of the fabricated devices was 0.02 $\mathrm{cm}^{2}$.

Power conversion efficiency was calculated from the current density-voltage $(\mathrm{J}-\mathrm{V})$ characteristics under a solar simulated light irradiation (AM1.5) at $100 \mathrm{~mW} / \mathrm{cm}^{2}$. The solar simulator used was the MAX-302 model (Asahi Spectra Co. Ltd., Japan) and this illuminator only absorbs light within the range of $350 \mathrm{~nm}$ to $750 \mathrm{~nm}$, without absorbing light of the near infrared region. Therefore, the short current density may be higher than that measured under real AM1.5 illumination. The J-V characteristics were evaluated by using a semiconductor characterization system (Keithley 2,400 LV) at room temperature.
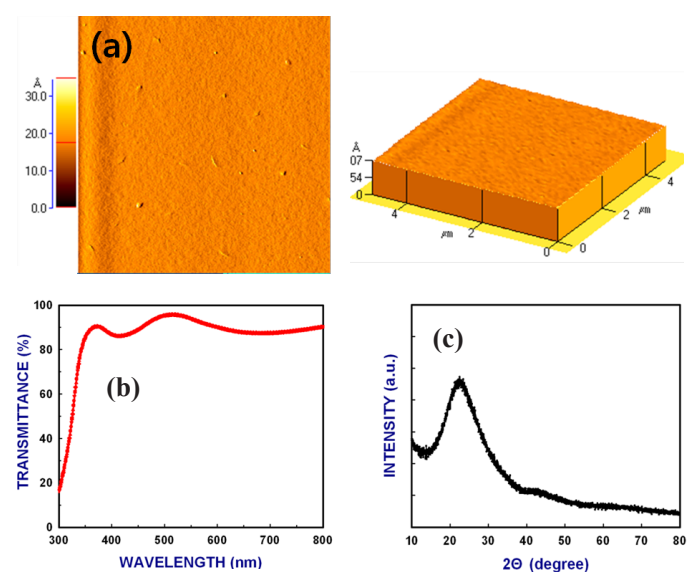

Fig. 2. (a) AFM images of the $\mathrm{TiO}_{\mathrm{x}}$ film observed by tapping mode, (b) Transmittance and (c) XRD spectrum of the spin-coated $\mathrm{TiO}_{\mathrm{x}}$ film on glass.
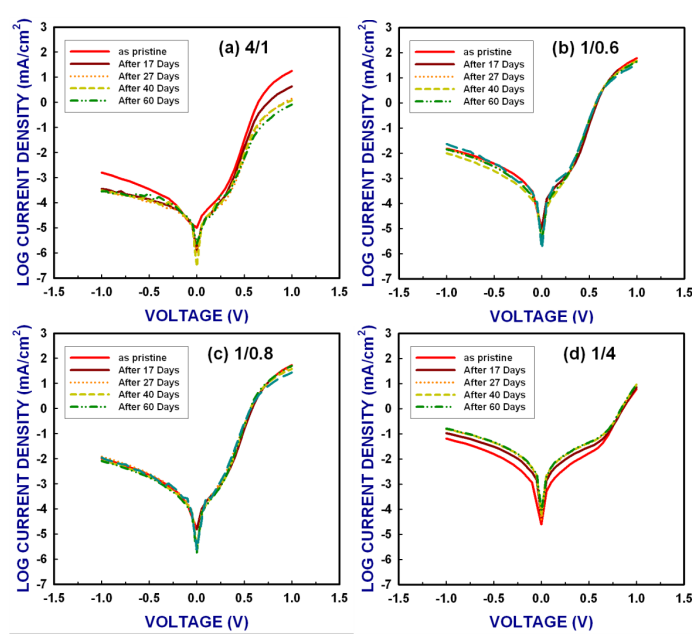

Fig. 3. J-V characteristics under dark condition with various blend ratios of P3HT and PCBM-71; (a) 4:1, (b) 1:0.6, (c) 1:0.8, and (d) 1:4.

\section{RESULTS AND DISCUSSION}

Figure 2 shows the AFM image observed by tapping mode, $\mathrm{UV} / \mathrm{Vis}$ spectroscopy, and XRD pattern of the $\mathrm{TiO}_{\mathrm{x}}$ film formed by spin-coating onto ITO substrate, respectively. The precursor solution was spin-coated on glass substrate with a thickness of about $30 \mathrm{~nm}$. Subsequently, during $1 \mathrm{~h}$ in air at room temperature, the precursor converted to $\mathrm{TiO}_{\mathrm{x}}$ by hydrolysis. The sample was then heated at $150^{\circ} \mathrm{C}$ for $10 \mathrm{~min}$ inside a glove box filled with nitrogen. The $\mathrm{TiO}_{\mathrm{x}}$ films were relatively transparent and smooth, with surface features smaller than a few nanometers. As can be seen in Fig. 2(c), the XRD pattern of $\mathrm{TiO}_{\mathrm{x}}$ film is amorphous, as confirmed by XRD. In spite of the amorphous nature of the $\mathrm{TiO}_{\mathrm{x}}$ layer, the physical properties are excellent. Time-of-flight measurements on these $\mathrm{TiO}_{\mathrm{x}}$ films indicate that the electron mobility is approximately $1.7 \times 10-4 \mathrm{~cm}^{2} / \mathrm{Vs}$, which is somewhat higher than mobility values obtained from amorphous oxide films prepared by typical sol-gel processes. According to reports in some papers, the $\mathrm{TiO}_{\mathrm{x}}$ layer satisfies the electronic-structure requirements of the optical spacer [23]. In this work, I applied the $\mathrm{TiO}_{\mathrm{x}}$ layer as an optical spacer to enhance the current density.

$\mathrm{J}-\mathrm{V}$ characteristics of the devices with various blend ratio of P3HT:PCBM-71 in dark condition and under illumination at 

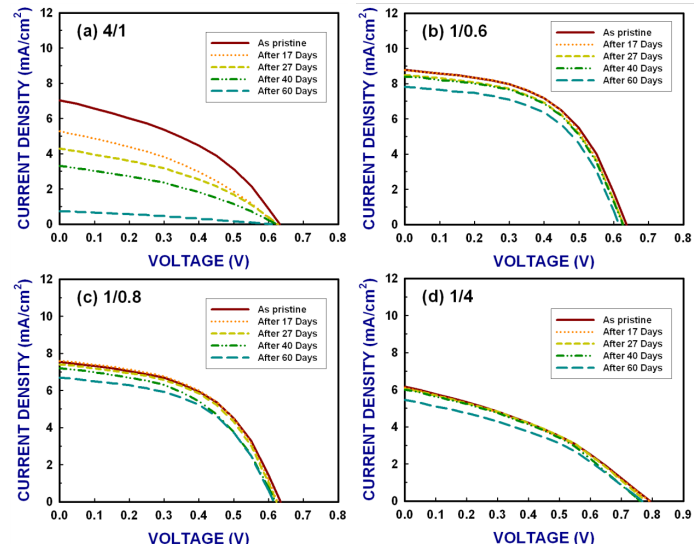

Fig. 4. J-V characteristics under illumination at $100 \mathrm{~mW} / \mathrm{cm}^{2} \mathrm{AM} 1.5$ with various blend ratios of P3HT and PCBM-71: (a) 4:1, (b) 1:0.6, (c) $1: 0.8$, and (d) 1:4.

AM1.5 (100 mW/ $\left.\mathrm{cm}^{2}\right)$ are shown in Fig. 3 and Fig. 4, respectively. I observed the variation of $\mathrm{J}-\mathrm{V}$ characteristics in the dark condition as a function of the blend ratio of P3HT:PCBM-71. The dark $\mathrm{J}-\mathrm{V}$ characteristic in Fig. 3 shows that current density in the reverse region was increased in the device with the blend ratio of 1:4 as the storage time increases. This behavior can be expected due to the deterioration of the active layer and/or the interface between the electrode and active layer $[21,24]$. This blend ratio indicates the reduction of current density in the forward region, due to the mismatch of hole-electron balance arising from the non-optimization of the P3HT:PCBM blend ratio.

Figure 4 shows the J-V characteristics under illumination of the devices with different blend ratios. The $\mathrm{J}_{\mathrm{SC}}$ of devices with a 4:1 blend ratio decreases from $9.4 \mathrm{~mA} / \mathrm{cm}^{2}$ to $1.0 \mathrm{~mA} / \mathrm{cm}^{2}$ as the storage time increases. From these results, I find that the P3HT cell stability is not adequate.

Generally, P3HT shows poor environmental stability compared to PCBM for oxygen, moisture, UV light and so on. Reference [25], seeking to understand light stability for the single layer P3HT, made an OPV device having a single layer P3HT, and measured the degree of degradation of cell parameters under illumination. The $\mathrm{J}_{\mathrm{SC}}$ decreases significantly with exposure time. It may be due to defects created during illumination. The current appears to decrease with illumination time by recombination through these defects. The generated defects shift the Fermi level to the midgap, leading to an increase in its resistivity. Note that the polymer used in the cell, P3HT, can degrade in the thin film structure containing the molecular oxygen when it is irradiated with UV or visible light $[25,26]$.

On the other hand, the devices with blend ratios of 1:0.6 and 1:0.8 are quite stable in the dark and under illumination conditions. In particular, I obtained the best cell performance for the blend ratio of 1:0.6. In the 1:0.6 case, the $\mathrm{J}_{\mathrm{SC}}, \mathrm{V}_{\mathrm{OC}}, \mathrm{FF}$, and PCE are initially $13.5 \mathrm{~mA} / \mathrm{cm}^{2}, 0.64 \mathrm{~V}, 51.8 \%$, and $4.5 \%$, respectively. In the $1: 0.8$ case, the $\mathrm{J}_{\mathrm{SC}}, \mathrm{V}_{\mathrm{OC}}, \mathrm{FF}$, and PCE are initially $11.6 \mathrm{~mA} / \mathrm{cm}^{2}$, $0.63 \mathrm{~V}, 50.8 \%$, and $3.7 \%$, respectively. For both devices, as the storage time is increased to 60 days, the $\mathrm{J}_{\mathrm{SC}}$ decreases to about $10 \%$ compared to its initial value, and other parameters show slight changes. I expect that this cell stability results from the good charge balance of hole and electron at the interface and the forming of a well-ordered morphology for the 1:0.6 and 1:0.8 ratios. However, the device with a blend ratio of $1: 4$, having a high content of PCBM-71, shows a higher $\mathrm{V}_{\mathrm{OC}}$ of $0.8 \mathrm{~V}$ than that of the other devices, while the $\mathrm{J}_{\mathrm{SC}}$ is $9.4 \mathrm{~mA} / \mathrm{cm}^{2}$ due to the low content of P3HT that has mainly absorbed the light.
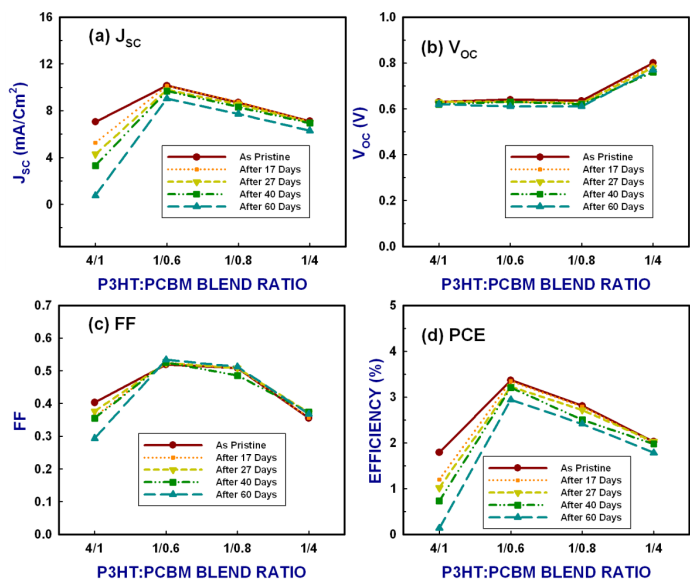

Fig. 5. Variation of the solar cell parameters of the devices with different blend ratios of P3HT and PCBM-71 from fabrication day to 60 days; (a) $\mathrm{J}_{\mathrm{SC}}$, (b) $\mathrm{V}_{\mathrm{OC}}$, (c) FF, and (d) Efficiency.

Table 1. Summary of the photovoltaic performances of the devices with different blend ratios as a function of storage time. All devices were kept in the dark and at room temperature condition and J-V measurement was made under AM1.5 illumination (at $100 \mathrm{~mW} / \mathrm{cm}^{2}$ ).

\begin{tabular}{cccccc}
\hline $\begin{array}{c}\text { Storage } \\
\text { Time }\end{array}$ & $\begin{array}{c}\text { Blend Ratio } \\
(\mathrm{P} 3 \mathrm{HT}: \mathrm{PCBM})\end{array}$ & $\begin{array}{c}\text { JSC } \\
\left(\mathrm{mA} / \mathrm{cm}^{2}\right)\end{array}$ & $\begin{array}{c}\text { VOC } \\
(\mathrm{V})\end{array}$ & $\begin{array}{c}\text { FF } \\
(\%)\end{array}$ & $\begin{array}{c}\text { PCE } \\
(\%)\end{array}$ \\
\hline \hline \multirow{4}{*}{ Initial } & $4: 1$ & 9.38 & 0.63 & 40.29 & 2.38 \\
& $1: 0.6$ & 13.51 & 0.64 & 51.87 & 4.49 \\
& $1: 0.8$ & 11.61 & 0.64 & 50.81 & 3.72 \\
After & $1: 4$ & 9.48 & 0.80 & 35.54 & 2.7 \\
60 days & $4: 1$ & 1.00 & 0.62 & 29.36 & 0.18 \\
& $1: 0.6$ & 12.03 & 0.61 & 53.40 & 3.92 \\
& $1: 0.8$ & 10.29 & 0.61 & 51.20 & 3.21 \\
& $1: 4$ & 8.27 & 0.77 & 36.78 & 2.34 \\
\hline
\end{tabular}

Figure 5 shows the variation of solar cell parameters of the device with various blend ratios as a function of storage time. Table 1 provides a summary of the photovoltaic performances of the devices with different blend ratios as a function of storage time. All devices were kept in the dark and at room temperature condition, and J-V measurement was made under AM1.5 illumination (at $100 \mathrm{~mW} / \mathrm{cm}^{2}$ ).

As can be seen in Fig. 5(a), the $\mathrm{J}_{\mathrm{SC}}$ significantly decreased as the content of P3HT was increased. The $\mathrm{J}_{\mathrm{SC}}$ of device with a 4:1 blend ratio of P3HT:PCBM-71 decreased to $\sim 90 \%$ after 60 days. On the other hand, the device with a 1:4 blend ratio P3HT:PCBM-71 showed a variation of $\sim 13 \%$ after 60 days, even though cell efficiency is low due to the mismatch between the charge balance of hole and electron. As a result, among the devices with different blend ratios, I find that the device with the most optimized blend ratio of 1:0.6 showed the best cell performance. Further, the device with the best cell efficiency leads to good cell stability.

\section{CONCLUSIONS}

I fabricated organic solar cells having P3HT:PCBM-71 as an active layer and with $\mathrm{TiO}_{\mathrm{x}}$ as an electron transport layer, and optimized the blend ratio of active layer to improve cell performance. I also investigated the stability of devices with different blend ratios as a function of storage time up to 60 days in the dark and under illumination conditions at $100 \mathrm{~mW} / \mathrm{cm}^{2}$ (AM1.5). I found that the more the P3HT ratio compared to PCBM in- 
creases within the active layer, the more the cell efficiency decreases. The blend ratio indicating the best cell performance was the 1:0.6 ratio of P3HT:PCBM-71, with $\mathrm{J}_{\mathrm{SC}}, \mathrm{V}_{\mathrm{OC}}, \mathrm{FF}$, and the PCE values of $13.5 \mathrm{~mA} / \mathrm{cm}^{2}, 0.64 \mathrm{~V}, 51.8 \%$, and $4.5 \%$, respectively. As a result, I find that the device with an optimized blend ratio shows the best cell efficiency, and leads to good cell stability.

\section{ACKNOWLEDGMENTS}

This work was supported by Woosuk University. The author deeply thanks Professor Jin Jang of the Advanced Display Research Center at Kyung Hee University, and Dr. Mi Sun Ryu of the TAKOMA Technology Company for providing organic solar cell equipment for fabrication and evaluation.

\section{REFERENCES}

[1] S. E. Shaheen, D. S. Ginley, and G. E. Jabbour Eds., Organicbased Photovoltaics, MRS Bulletin 30 (2005) [DOI: 10.1557/ mrs2005.2].

[2] S. H. Park, A. Roy, S. Beaupré, S. Cho, N. Coates, J. S. Moon, D. Moses, M. Leclerc, K. H. Lee and A. J. Heeger, Nat. Phot. 3, 297 303 (2009) [DOI: 10.1038/nphoton.2009.69].

[3] Y. Liang, Z. Xu, J. Xia, S. T. Tsai, Y. Wu, G. Li, C. Ray and L. Yu, Adv. Mater. 22, E135-E138 (2010) [DOI: 10.1002/adma.200903528].

[4] G. Zhao, Y. He and Y. Li, Adv. Mater. 22, 4355-4358 (2010) [DOI: 10.1002/adma.201001339].

[5] Y. J. Cheng, C. H. Hsieh, Y. J. He, C.S. Hsu and Y. F. Li, J. Am. Chem. Soc. 132, 17381-17383 (2010) [DOI: 10.1021/ja108259n].

[6] H. J. Son, W. Wang, T. Xu, Y. Liang, Y. Wu, G. Li and L. Yu, J. Am. Chem. Soc. 133, 1885-1894 (2011) [DOI: 10.1021/ja108601g].

[7] S. C. Price, A.C. Stuart, L. Yang, H. Zhou, and W. You, J. Am. Chem. Soc. 133, 4625-4631(2011) [DOI: 10.1021/ja1112595].

[8] T. Y. Chu, J. Lu, S. BeauprØ, Y. Zhang, J. R. Pouliot, S. Wakim, J. Zhou, M. Leclerc, Z. Li, J. Ding and Y. Tao, J. Am. Chem. Soc. 133, 4250 -4253 (2011) [DOI: 10.1021/ja200314m].

[9] M. Reyes-Reyes, K. Kim, and D. Carroll, Appl. Phys. Lett. 87 0083506 (2005) [DOI: 10.1063/1.2006986].

[10] W. Ma, C. Yang, X. Gong, K. Lee, and A. J. Heeger, Adv. Funct.
Mater. 15, 1617 (2005) [DOI: 10.1002/adfm.200500211].

[11] S. A. Gevorgyan, M. Jørgensen, F. C. Krebs, Sol. Energy Mater. Sol. Cells, 92(7), 736 (2008) [DOI: 10.1016/j.solmat.2008.02.008].

[12] F. C. Krebs, J. Alstrup, H. Spanggaard, K. Larsen, and E. Kold, Sol. Energy Mater. Sol. Cells 83, 293 (2004) [DOI: 10.1016/ j.solmat.2004.02.031].

[13] E. Bundgaard and F. C. Krebs, Pol. Bull. 55, 157 (2005) [DOI: 10.1007/s00289-005-0423-0].

[14] F. C. Krebs, J. Alstrup, M. Biancardo, and H. Spanggaard, Proc. SPIE 5938, 593804 (2005) [DOI: 10.1117/12.613438].

[15] F. C. Krebs, M. Biancardo, B. Winther-Jensen, and H. Spanggaard, J. Alstrup, Sol. Energy Mater. Sol. Cells 90, 1058 (2006) [DOI: 10.1016/j.solmat.2005.06.003].

[16] B. Winther-Jensen and F. C. Krebs, Sol. Energy Mater. Sol. Cells 90, 123 (2006) [DOI: 10.1016/j.solmat.2005.02.004].

[17] F. C. Krebs, H. Spanggaard, T. Kjær, M. Biancardo, and J. Alstrup, Mater. Sci. Eng. B 138, 106 (2007) [DOI: 10.1016/ j.mseb.2006.06.008].

[18] E. Bundgaard and F.C. Krebs, Sol. Energy Mater. Sol. Cells 91, 1019 (2007) [DOI: 10.1016/j.solmat.2007.01.013].

[19] M. H. Petersen, O. Hagemann, K. T. Nielsen, M. Jørgensen, and F. C. Krebs, Sol. Energy Mater. Sol. Cells 91, 996 (2007) [DOI: 10.1016/j.solmat.2007.02.022].

[20] M. Andersen, J.E. Carle', N. Cruys-Bagger, M. R. Lilliedal, M. A. Hammond, B. Winther-Jensen, and F.C. Krebs, Sol. Energy Mater. Sol. Cells 91, 539 (2007) [DOI: 10.1016/j.solmat.2006.11.006].

[21] M. Jørgensen, K. Norrman, and F. C. Krebs, Sol. Energy Mater. Sol. Cells 92, 686 (2008) [DOI: 10.1016/j.solmat.2008.01.005].

[22] S.H. Park, A. Roy1, S. Beaupre, S. Cho, N. Coates, J.S. Moon, D. Moses, M. Leclerc, K. Lee, and A.J. Heeger, Nat. Photo. 3, 297 (2009) [DOI: 10.1038/nphoton.2009.69].

[23] J. Y. Kim, S.H. Kim, H. H. Lee, K. Lee, W. Ma, X. Gong, and A. J. Heeger, Adv. Mater. 18, 572 (2006) [DOI: 10.1002/ adma.200501825].

[24] F. C. Krebs and K. Norrman, Prog. Photovolt: Res. Appl. 15, 697 (2007) [DOI: 10.1002/pip.794].

[25] M.S. Ryu, H.J. Cha, and J. Jang, Sol. Energy Mater. Sol. Cells 94, 152 (2010) [DOI: 10.1016/j.solmat.2009.08.011].

[26] M.S.A. Abdou and S. Holdcroft, Macromolecules 26, 2954 (1993) [DOI: 10.1021/ma00063a047]. 